Article

\title{
Fatty Acid Signatures in Different Tissues of Mediterranean Yellowtail, Seriola dumerili (Risso, 1810), Fed Diets Containing Different Levels of Vegetable and Fish Oils
}

\author{
Francesco Bordignon ${ }^{1}{ }^{\complement}$, Ana Tomás-Vidal ${ }^{2}$, Angela Trocino ${ }^{1, *} \mathbb{C}$, Maria C. Milián Sorribes ${ }^{2}$, \\ Miguel Jover-Cerdá ${ }^{2}$ and Silvia Martínez-Llorens ${ }^{2}$ \\ 1 Department of Comparative Biomedicine and Food Science (BCA), University of Padova, Viale \\ dell'Università 16, I-35020 Legnaro, Italy; francesco.bordignon.3@phd.unipd.it \\ 2 Institute of Animal Science and Technology, Group of Aquaculture and Biodiversity, Universitat Politècnica \\ de València, Camino de Vera, 14, 46071 València, Spain; atomasv@dca.upv.es (A.T.-V.); \\ mamisor@etsia.upv.es (M.C.M.S.); mjover@dca.upv.es (M.J.-C.); silmarll@dca.upv.es (S.M.-L.) \\ * Correspondence: angela.trocino@unipd.it; Tel.: +39-0498272583
}

Received: 28 December 2019; Accepted: 21 January 2020; Published: 24 January 2020

Simple Summary: Most of the studies performed to date mainly investigated on the effects of dietary substitution of fish oil with vegetable oils on growth and fatty acid composition of edible muscle tissues. On the other hand, a few assessed how dietary lipids are retained in other tissues, such as brain, liver, and adipose tissue, which would provide further insights into the fatty acid requirements of new farmed marine fish species such as Seriola dumerili. Thus, this study evaluated how the replacement of fish oil with different proportions of vegetable oils in diets affects the tissue-specific fatty acid composition (also known as signature) of brain, muscle, liver, and visceral fat of S. dumerili. The fatty acid composition of the diet had a strong effect on the fatty acid signature of muscle, liver, and visceral fat, whereas the brain signature was less sensitive to dietary changes. These new insights contribute to identify the essential fatty acids requirements of Mediterranean yellowtail and to define the conditions under which the physiological functions in these fish are preserved when they are fed diets with low fish oil levels to guarantee the sustainability of their production and welfare.

\begin{abstract}
The study aimed to evaluate how replacing different proportions of fish oil (FO) with vegetable oils (VO) in the diet of Mediterranean yellowtail, Seriola dumerili (Risso, 1810), affects the fatty acids (FA) signature, i.e., overall FA profile, in different tissues. A total of 225 Mediterranean yellowtail juveniles (initial live weight: $176 \pm 3.62 \mathrm{~g}$ ) were fed for 109 days with one of three diets: A control diet (FO 100), with FO as the only lipid source, or diets with $75 \%$ and $100 \%$ of FO replaced with a VO mixture. At the end of the feeding trial, the brains, muscles, livers, and visceral fat were sampled in four fish per tank (12 per treatment), and their fat were extracted and used for FA analysis. The FA signatures of red and white muscle, liver, and visceral fat tissues changed when the dietary FA source changed, whereas FA signatures in the brain were rather robust to such dietary changes. These new insights might help evaluate whether key physiological functions are preserved when fish are fed diets with low FO levels, as well as define the dietary FA requirements of Mediterranean yellowtail to improve the sustainability of the production and welfare of the fish.
\end{abstract}

Keywords: brain; muscle; liver; greater amberjack; EPA; DHA 


\section{Introduction}

The Mediterranean yellowtail, Seriola dumerili (Risso, 1810), also called the greater amberjack, is a new, high-value candidate for production in marine aquaculture. This cosmopolitan fish is mainly produced in Japan [1], Spain [2], Italy [3], and recently in Vietnam, Korea, and China [4]. It has high growth rates (reaching $6 \mathrm{~kg}$ within 2.5 years of culture), and exceptionally high consumer acceptance [4,5].

Since the Mediterranean yellowtail is an emerging species in aquaculture, its nutritional requirements have been defined in terms of major nutrients $(47 \%-50 \%$ crude protein $(\mathrm{CP})$ and $12 \%-14 \%$ crude lipid (CL)) [6-10]; however, little information is available on its fatty acid requirements [11], which thus require further investigation. Only one previous study assessed the effects of dietary fatty acids on Mediterranean yellowtail body composition [11].

Fatty acids (FA) play key roles in fish health and nutrition. They maintain the structural and functional integrity of cell membranes, provide metabolic energy through their oxidative metabolism, contribute to visual and brain development, and are precursors of a group of paracrine hormones with relevant biological roles known as eicosanoids [12-14]. Fish health, growth, and reproduction are strongly dependent on n-3 and n-6 polyunsaturated fatty acids (PUFA), especially arachidonic acid (AA, C20:4 n-6), eicosapentaenoic acid (EPA, C20:5 n-3), and docosahexaenoic acid (DHA, C22:6 n-3) [13,15-17]. However, marine carnivorous fish such as $S$. dumerili have limited ability to bio-convert the essential precursors of PUFA, such as linoleic acid (LA, C18:2 n-6) and alpha-linolenic acid (ALA, C18:3 n-3), into these essential FA [18,19].

The overall fatty acid profile within a given tissue, also known as its FA signature [20], is strongly dependent on the physiological function(s) of the tissue itself [21]. The liver and muscles are the main sites of $\beta$-oxidation [22], whereas the brain stores n-3 LC-PUFA, mainly DHA, which perform neurological functions [23-25]. Nevertheless, in nature, the FA signatures of prey tissues can be transferred to their predators with little modification and in a predictable manner $[20,26,27]$. Thus, in recent decades, FA have been extensively used as biomarkers in riverine and marine ecosystems [20,28,29]. Additionally, under farming conditions [30-32], the available literature collectively supports the conclusion that there is a close association between the diet and fillet FA composition in farmed fish, as reviewed by Turchini et al. [19].

As in other species [33], understanding the FA distributions and signatures within Mediterranean yellowtail tissues might help us understand whether the physiological needs and essential fatty acid (EFA) requirements of fish are satisfied under farming conditions. This is particularly crucial when diets that contain low levels of fish oil (FO) are used in fish farming. In fact, to ensure the long-term sustainability of the aquaculture sector and to improve its competitiveness, FO has been increasingly replaced by vegetable oils (VO) in fish diets because FO has a high cost and is available in finite and limited amounts [19]. Compared to FO, plant seed oils are rich in C:18 PUFA [19], but lacking in n-3 highly unsaturated fatty acids (HUFA), which are essential for marine fish [13].

Most studies performed in farmed fish to date have focused mainly on the effects of dietary lipids on the FA composition of edible muscle tissues [19]. Only one study [33], which investigated FA signatures in gilthead seabream (Sparus aurata L.; 1758), assessed how dietary lipids were retained in different tissues (brain, liver, and mesenteric adipose tissue) to obtain further insights into the FA requirements of farmed marine fish.

Therefore, this study was performed to evaluate how the replacement of FO with different proportions of VO in the diet affects the tissue-specific FA signatures and their robustness in the brain, muscle, liver, and visceral fat tissues of Mediterranean yellowtail (S. dumerili).

\section{Materials and Methods}

A feeding trial was performed at the Fish Nutrition Laboratory (LAC) of the Institute of Animal Science and Technology (ICTA) of the Universitat Politècnica de València (Polytechnic University of Valencia, Spain). The experimental protocol was approved by the Committee of Ethics and Animal 
Welfare of the Polytechnic University of Valencia, following the Spanish Royal Decree 53/2013 on the protection of animals used for scientific purposes.

The facility used a thermoregulated recirculating seawater system $\left(65 \mathrm{~m}^{3}\right.$ capacity), with a rotary drum-type filter and a mechanical gravity biofilter with a volume of $2 \mathrm{~m}^{3}$, equipped with 9 cylindrical fiberglass tanks with a capacity of $1750 \mathrm{~L}$ each with aeration.

\subsection{Experimental Diets}

Three isoproteic (59\% CP, 50\% digestible protein (DP)), and isolipidic (15\% CL) extruded diets were formulated, with increasing levels of vegetable oils used to replace the fish oil in the diets as follows: 0\% (control diet, FO 100), 75\% (FO 25), and 100\% (FO 0) replacement of FO with VO (Table 1). The mixture of vegetable oils used consisted of linseed oil, sunflower oil, and palm oil (4:3:3). Diets were prepared using a cooking-extrusion processor with a semi-industrial twin-screw extruder (CLEXTRAL BC-45; Firmity, St Etienne, France), at a screw speed of $100 \mathrm{rpm}$, temperature of $110^{\circ} \mathrm{C}$, and pressure of 40-50 atm, to obtain pellets $2-3 \mathrm{~mm}$ in diameter.

Table 1. Ingredients ( $\mathrm{g} \mathrm{kg}^{-1}$ as fed) and proximate composition (\% dry matter; DM) of the experimental diets.

\begin{tabular}{|c|c|c|c|}
\hline & \multicolumn{3}{|c|}{ Diet } \\
\hline & FO 100 & FO 25 & FO 0 \\
\hline Fish meal & 350 & 350 & 350 \\
\hline Wheat & 100 & 100 & 100 \\
\hline Wheat gluten & 140 & 140 & 140 \\
\hline Defatted soybean meal & 185 & 185 & 185 \\
\hline Iberian meat meal & 110 & 110 & 110 \\
\hline Fish oil & 95 & 24 & 0 \\
\hline Linseed oil & - & 28 & 38 \\
\hline Sunflower oil & - & 21 & 28 \\
\hline Palm oil & - & 22 & 29 \\
\hline Multivitamin and minerals mix & 20 & 20 & 20 \\
\hline \multicolumn{4}{|l|}{ Proximate composition } \\
\hline Dry matter, \% & 87.4 & 88.8 & 89.1 \\
\hline Crude protein, \% DM & 58.8 & 60.6 & 58.8 \\
\hline Crude lipid, \% DM & 15.9 & 15.1 & 16.6 \\
\hline Ash, \%DM & 8.4 & 10.3 & 8.3 \\
\hline Gross energy, $\mathrm{MJ} \mathrm{kg}{ }^{-1} \mathrm{DM}$ & 24.3 & 23.8 & 24.4 \\
\hline
\end{tabular}

Fish oil (FO) 100 diet: Diet formulated with fish oil as lipid source; FO 25 diet: Diet in which fish oil was included at a content of 25\%; FO 0 diet: Diet in which fish oil was totally substituted with vegetable oil. ${ }^{1}$ Vitamins and mineral mixture (values are $\mathrm{g} \mathrm{kg}^{-1}$ ): Premix, 25; Hill, 10; DL- $\alpha$-tocopherol, 5; ascorbic acid, 5; $\left(\mathrm{PO}_{4}\right)_{2} \mathrm{Ca}_{3}, 5$. Premix composition (values are IU kg ${ }^{-1}$ ): Retinol acetate, 1,000,000; calcipherol, 500; DL- $\alpha$-tocopherol, 10; menadione sodium bisulphite, 0.8; hidroclorhidrate thiamine, 2.3; riboflavin, 2.3; pyridoxine hydrochloride, 15; cyanocobalamin, 25; nicotinamide, 15; pantothenic acid, 6; folic acid, 0.65; biotin, 0.07; ascorbic acid, 75; inositol, 15; betaine, 100; polypeptides, 12 .

The FA profile of the experimental diets changed depending on the relative proportions of the two lipid sources included in them. Diets containing more FO contained higher proportions of highly unsaturated fatty acids from the n-3 series, whereas diets containing more vegetable oils had higher proportions of LA and ALA (Table 2). In all diets, C16:0 accounted for the bulk of the saturated fatty acids (SFA) present, C18:1n-9 for most of the monounsaturated fatty acids (MUFA), and EPA and ARA for most of the n-3 long-chain polyunsaturated fatty acids (PUFA). The inclusion of VO as a lipid source increased the dietary proportion of C18:1 n-9 (27.1\%, 29.6\%, and 32.7\%), C18:1 n-6 (12.7\%, 13.4\%, and $14.9 \%)$, and $\operatorname{ALA}(14.1 \%, 14.3 \%$, and $15.4 \%)$, whereas it decreased the proportions of total SFA, EPA, and docosahexaenoic acid (DHA) in the diets (SFA: 27.8\%, 27.1\%, and 25.5\% in the FO 100, FO 25, and FO 0 diets, respectively; EPA: 5.81\%, 4.34\%, and 2.77\%; DHA: 13.0\%, 7.6\%, and 4.3\%) (Table 2). 
Table 2. Fatty acid composition (\% of total fatty acid content) of the experimental diets.

\begin{tabular}{|c|c|c|c|}
\hline & \multicolumn{3}{|c|}{ Diet } \\
\hline & FO 100 & FO 25 & FO 0 \\
\hline $14: 0$ & 3.28 & 2.38 & 1.65 \\
\hline $16: 0$ & 18.88 & 19.58 & 18.93 \\
\hline $17: 0$ & 0.53 & 0.24 & 0.16 \\
\hline $18: 0$ & 5.07 & 4.88 & 4.71 \\
\hline$\Sigma$ SFA & 27.79 & 27.12 & 25.46 \\
\hline $16: 1 n-9$ & 4.22 & 2.77 & 1.82 \\
\hline $18: 1 \mathrm{n}-9$ & 27.14 & 29.64 & 32.67 \\
\hline $18: 1 \mathrm{n}-7$ & 3.94 & 2.94 & 2.44 \\
\hline $22: 1 n-9$ & 0.32 & 0.04 & 0.06 \\
\hline$\Sigma$ MUFA & 35.62 & 35.39 & 36.99 \\
\hline $18: 2 n-6$ & 12.66 & 13.36 & 14.86 \\
\hline $18: 3 n-6$ & 0.10 & 0.09 & 0.09 \\
\hline $20: 3 n-6$ & 0.10 & 0.04 & 0.04 \\
\hline $20: 4 n-6$ & 1.02 & 0.58 & 0.35 \\
\hline $22: 4 n-6$ & 0.24 & 0.19 & 0.09 \\
\hline$\Sigma$ n-6 PUFA & 14.12 & 14.26 & 15.43 \\
\hline $18: 3 n-3$ & 2.24 & 10.48 & 14.60 \\
\hline $20: 3 n-3$ & 0.15 & 0.08 & 0.06 \\
\hline $20: 5 n-3$ & 5.81 & 4.34 & 2.77 \\
\hline $22: 5 n-3$ & 1.29 & 0.73 & 0.42 \\
\hline $22: 6 n-3$ & 12.98 & 7.61 & 4.28 \\
\hline$\Sigma \mathrm{n}-3$ PUFA & 22.47 & 23.24 & 22.13 \\
\hline$\Sigma$ PUFA & 36.59 & 37.50 & 37.56 \\
\hline$\sum n-6 / \sum n-3$ & 0.63 & 0.61 & 0.70 \\
\hline DHA/EPA & 2.23 & 1.76 & 1.54 \\
\hline
\end{tabular}

FO 100 diet: Diet formulated with fish oil as lipid source; FO 25 diet: Diet in which fish oil was included at a content of 25\%; FO 0 diet: Diet in which fish oil was totally substituted with vegetable oil. Abbreviations: SFA: Saturated fatty acids; MUFA: Monounsaturated fatty acids; PUFA: Polyunsaturated fatty acids; DHA/EPA: 22:6 n-3/20:5 n-3.

\subsection{Fish and Experimental Design}

A total of 225 Mediterranean yellowtail juveniles obtained from a private hatchery (Futuna Blue S.A.; Cádiz, Spain) were transported to the Fish Nutrition Laboratory of the Universitat Politècnica de València for use in the feeding trial. After four weeks of acclimation, fish were individually weighed (initial weight: $176 \pm 3.62 \mathrm{~g}$ ), randomly distributed among nine tanks (25 fish per tank), and fed the experimental diets (FO 100, FO 25, or FO 0, with three tanks per diet) for 109 days.

During the trial, the water temperature averaged $21.5 \pm 2.4{ }^{\circ} \mathrm{C}$, the salinity was $31.5 \pm 4.1 \mathrm{~g}$ $\mathrm{L}^{-1}$, and the dissolved oxygen content was $8.0 \pm 0.4 \mathrm{mg} \mathrm{L}^{-1}$. The water $\mathrm{pH}$ ranged from 7.5 to 8.0 , and the levels of nitrogenous compounds in the water were kept within the limits recommended for marine species.

\subsection{In Vivo Recordings}

Feed was distributed by hand, twice a day (at 09:00 and 16:00) for six days per week, until apparent satiation. Feed intake was recorded at each administration. Mortality was checked every day. At the beginning and at the end of the trial, fish were individually weighed after one day of feed deprivation and under light anaesthesia (10 $\mathrm{mg} \mathrm{L}^{-1}$ clove oil containing 87\% eugenol; Guinama ${ }^{\circledR}$, Valencia, Spain). Fish health during weighing was assessed by direct observation.

After 109 days of feeding, four fish per tank (12 per treatment, 36 in total) were randomly sacrificed by lethal immersion in clove oil $\left(150 \mathrm{mg} \mathrm{L}^{-1}\right)$. Fish were dissected to sample their brain, white and red muscle, liver, and visceral fat tissues, which were then frozen in liquid nitrogen and stored at $-80^{\circ} \mathrm{C}$ until subsequent analyses.

\subsection{Chemical Analyses of Diets and Fish Tissues}

Diets were ground up and analysed according to AOAC procedures [34] to determine their dry matter (by heating at $105^{\circ} \mathrm{C}$ until a constant weight was attained), ash (by incinerating them at 550 
${ }^{\circ} \mathrm{C}$ for $5 \mathrm{~h}$ ), crude protein (AOAC official method 990.03, by the DUMAS direct combustion method, using a LECO CN628 apparatus, LECO, ST. Joseph, MI, USA), and crude lipid content (by extraction with methyl ether using an ANKOMXT10 extractor, ANKOM Technology, Macedon, NY, USA). Gross energy content (GE) was calculated according to Brouwer [35], from the $\mathrm{C}(\mathrm{g})$ and $\mathrm{N}(\mathrm{g})$ balance in the feed $(\mathrm{GE}=51.8 \times \mathrm{C}-19.4 \times \mathrm{N})$. The carbon and nitrogen content were analysed based on the Dumas principle (TruSpec CN; Leco Corporation, St Joseph, MI, USA). All analyses were performed in triplicate.

After thawing, tissues were minced and homogenised. The crude fats in the brain, muscle, liver, and visceral fat tissue sampled were then extracted [36]. A direct method of fatty acid methyl ester (FAME) synthesis was used for this procedure [37]. The analysis of brain, muscle, liver, and visceral fat tissues was carried out using 10-30 mg of extracted crude fat from each tissue. First, $1 \mathrm{~mL}$ of tridecanoic acid (C13:0) was used as internal standard. Then, $0.7 \mathrm{~mL}$ of $10 \mathrm{~N} \mathrm{KOH}$ and $5.3 \mathrm{~mL}$ of HPLC (high-performance liquid chromatography)-quality methanol were added. Tubes were incubated at 55 ${ }^{\circ} \mathrm{C}$ in a thermoblock for $1.5 \mathrm{~h}$, and underwent vigorous shaking for $5 \mathrm{~s}$ every $20 \mathrm{~min}$. After cooling at ambient temperature in a water bath, $1.5 \mathrm{~mL}$ of HPLC-quality hexane was added to the reaction tubes, which were then vortex-mixed and centrifuged at $1006 \times g$ for $5 \mathrm{~min}$. After this, the hexane layer, containing the FAMEs, was placed into vials for analysis by gas chromatography. The vials were kept at $-80^{\circ} \mathrm{C}$ until gas chromatography was performed. The FAMEs were analysed in a Focus gas chromatograph (Thermo, Milan, Italy) equipped with a split/splitless injector and a flame ionisation detector. Separation of the methyl esters was performed in a SPTM 2560 fused silica capillary column (Supelco, PA, USA) $(100 \mathrm{~m} \times 0.25 \mathrm{~mm} \times 0.2 \mu \mathrm{m}$ film thickness). Helium was used as the carrier gas at a flow rate of $20 \mathrm{~cm} \mathrm{~s}^{-1}$. Samples were injected with a split ratio of 1:100.

The initial oven temperature, set at $140{ }^{\circ} \mathrm{C}$, was held constant for $5 \mathrm{~min}$, and then increased by $4{ }^{\circ} \mathrm{C}$ $\min ^{-1}$ to $240^{\circ} \mathrm{C}$, at which this temperature was then maintained for $30 \mathrm{~min}$. The FA were identified by comparing their retention times with those of the standards supplied by Supelco. The content of each type of FA was expressed as the percentage of the total FA content.

\subsection{Statistical Analyses}

The fish live weight, tissue fat content, and FA composition data were compared by analysis of variance (ANOVA), with diet included as the main effect and tank included as a random effect. The PROC MIXED procedure of the Statistical Analysis System (SAS) software [38] was used for all analyses. Adjusted means were compared among treatment levels using Bonferroni's t-test. Differences between means with $p \leq 0.05$ were considered statistically significant.

\section{Results}

In the present study of $S$. dumerili juveniles (176 $\mathrm{g}$ of initial live weight), diets containing only VO as the lipid source had no effect on fish growth (Figure 1). In fact, fish fed FO 100, FO 25, and FO 0 diets reached a final weight of 423,409 , and $419 \mathrm{~g}$, respectively $(p>0.05)$. The survival rate was lower in fish fed diets without fish oil compared with those in fish fed diets containing 100\% (FO 100) or 25\% (FO 25) fish oil (80.3\% vs. 89.7\% and 92.7\%, respectively; $p<0.05$ ) (Figure 1 ).

\subsection{Brain}

With regard to the brain, the dietary treatment did not affect the proportions of total SFA ( $32.9 \%$ of the total FA on average), MUFA (29.2\%), PUFA (37.9\%), n-3 PUFA (29.6\%), or n-6 PUFA (8.0\%) present in the tissue $(p>0.05)$ (Table 3). Nevertheless, the replacement of FO with VO decreased the relative content of EPA (3.01\% vs. $2.81 \%$ and $2.85 \%$ in FO 100 vs. FO 25 and FO 0, respectively; $p<0.001$ ) and DHA (23.8\% vs. $21.4 \%$ in FO 100 and FO 25 vs. FO $0 ; p<0.01)$, whereas it increased the content of ALA $(0.81 \%$ vs. $1.63 \%$ vs. $2.66 \%$ in FO 100 vs. FO 25 vs. FO $0 ; p<0.001)$. 


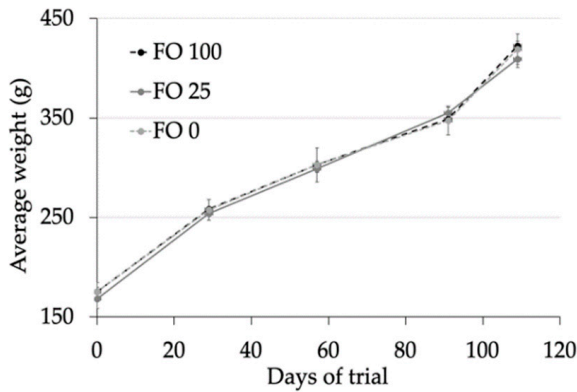

(a)

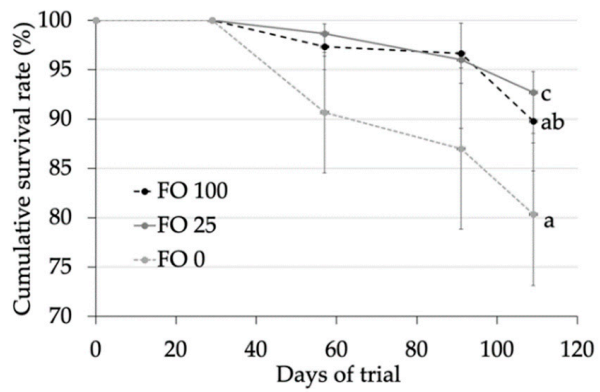

(b)

Figure 1. (a) Fish live weight (g) and (b) survival (\%) of fish fed experimental diets during the 109 days of trial. Values are expressed as means \pm standard error.

Table 3. Fat content and fatty acid composition (\% of total fatty acid content) of the brain in Mediterranean yellowtail fed the experimental diets ( $n=12$ per diet). Values are expressed as least square (LS)means.

\begin{tabular}{|c|c|c|c|c|c|}
\hline & \multicolumn{3}{|c|}{ Diet } & \multirow{2}{*}{$p$-Value } & \multirow{2}{*}{ RSD } \\
\hline & FO 100 & FO 25 & FO 0 & & \\
\hline Fat, \% WW & 3.22 & 4.23 & 3.52 & 0.999 & 0.951 \\
\hline \multicolumn{6}{|l|}{ Fatty acids, $\%$} \\
\hline 10:0 & 0.42 & 0.46 & 0.57 & 0.083 & 0.138 \\
\hline 14:0 & 0.76 & 0.64 & 0.68 & 0.134 & 0.141 \\
\hline $15: 0$ & $0.12^{b}$ & $0.10^{\mathrm{a}}$ & $0.09^{a}$ & $<0.001$ & 0.000 \\
\hline $16: 0$ & 16.31 & 16.54 & 16.21 & 0.378 & 0.563 \\
\hline $17: 0$ & $0.19^{b}$ & $0.14^{\mathrm{a}}$ & $0.14^{\mathrm{a}}$ & 0.006 & 0.000 \\
\hline $18: 0$ & 11.42 & 11.76 & 11.45 & 0.367 & 0.625 \\
\hline $20: 0$ & 0.46 & 0.44 & 0.44 & 0.475 & 0.045 \\
\hline $22: 0$ & 0.79 & 0.76 & 0.75 & 0.618 & 0.105 \\
\hline $24: 0$ & 2.41 & 2.35 & 2.20 & 0.387 & 0.318 \\
\hline$\Sigma \mathrm{SFA}$ & 32.90 & 33.17 & 32.51 & 0.278 & 0.932 \\
\hline $16: 1 \mathrm{n}-9$ & $2.67^{b}$ & $2.40^{\mathrm{a}}$ & $2.34^{\mathrm{a}}$ & $<0.001$ & 0.114 \\
\hline $17: 1 \mathrm{n}-10$ & 0.55 & 0.49 & 0.52 & 0.824 & 0.235 \\
\hline $18: 1$ n-9 & $20.33^{a b}$ & $19.93^{a}$ & $21.49^{b}$ & 0.009 & 1.050 \\
\hline $18: 1 \mathrm{n}-7$ & $2.80^{b}$ & $2.58^{a b}$ & $2.46^{\mathrm{a}}$ & 0.005 & 0.148 \\
\hline $20: 1 \mathrm{n}-9$ & $0.70^{b}$ & $0.59^{a}$ & $0.59^{a}$ & $<0.001$ & 0.063 \\
\hline $22: 1 \mathrm{n}-9$ & 0.32 & 0.32 & 0.28 & 0.271 & 0.045 \\
\hline $24: 1 \mathrm{n}-9$ & 2.16 & 2.07 & 1.98 & 0.378 & 0.261 \\
\hline$\Sigma$ MUFA & 29.47 & 28.44 & 29.66 & 0.139 & 1.336 \\
\hline $18: 2 \mathrm{n}-6$ & $4.25^{\mathrm{a}}$ & $4.39^{a}$ & $5.55^{b}$ & 0.016 & 1.080 \\
\hline $20: 2 n-6$ & 0.26 & 0.23 & 0.25 & 0.298 & 0.055 \\
\hline $20: 4 n-6$ & $2.65^{b}$ & $2.51^{b}$ & $2.27^{\mathrm{a}}$ & $<0.001$ & 0.187 \\
\hline $22: 2 n-6$ & $0.23^{b}$ & $0.19^{a b}$ & $0.18^{a}$ & 0.028 & 0.045 \\
\hline $22: 4 n-6$ & 0.22 & 0.22 & 0.18 & 0.150 & 0.055 \\
\hline$\Sigma$ PUFA n-6 & 7.74 & 7.69 & 8.54 & 0.077 & 0.967 \\
\hline $18: 3 n-3$ & $0.81^{\mathrm{a}}$ & $1.63^{b}$ & $2.66^{c}$ & $<0.001$ & 0.644 \\
\hline $20: 3 n-3$ & $0.10^{\mathrm{a}}$ & $0.16^{b}$ & $0.19^{b}$ & $<0.001$ & 0.032 \\
\hline $20: 5 n-3$ & $3.01^{b}$ & $2.81^{\mathrm{a}}$ & $2.85^{\mathrm{a}}$ & $<0.001$ & 0.118 \\
\hline $22: 5 n-3$ & 2.13 & 2.26 & 2.14 & 0.483 & 0.219 \\
\hline $22: 6 n-3$ & $23.83^{b}$ & $23.83^{b}$ & $21.43^{a}$ & 0.006 & 1.668 \\
\hline$\Sigma$ PUFA n-3 & 29.89 & 30.71 & 29.27 & 0.120 & 1.127 \\
\hline$\Sigma$ PUFA & 37.63 & 38.32 & 37.83 & 0.176 & 0.823 \\
\hline$\sum n-6 / \sum n-3$ & 0.26 & 0.25 & 0.30 & 0.098 & 0.041 \\
\hline DHA/EPA & $7.95^{\mathrm{ab}}$ & $8.50^{b}$ & $7.54^{\mathrm{a}}$ & 0.023 & 0.780 \\
\hline
\end{tabular}

FO 100 diet: Diet formulated with fish oil as lipid source; FO 25 diet: Diet in which fish oil was included at a content of $25 \%$; FO 0 diet: Diet in which fish oil was totally substituted with vegetable oil. Abbreviations: WW: Wet weight; RSD: Residual standard deviation; SFA: Saturated fatty acids; MUFA: Monounsaturated fatty acids; PUFA: Polyunsaturated fatty acids; DHA/EPA: 22:6 n-3/20:5 n-3. The FA $<0.1 \%$ of the total FA (i.e., C12:0, C14:1, C18:3 $\mathrm{n}-6$, and C30:3 n-6) are not given in the table. Different superscript letters indicate significant statistical differences among diets $(p \leq 0.05)$. 


\subsection{Liver}

In the liver, the replacement of FO with VO in the diet significantly decreased $(p<0.001)$ the proportion of the total SFA (24.3\% and $23.3 \%$ vs. $20.2 \%$ of the total FA in FO 100 and FO 25 vs. FO 0), which was due to the lower proportion of C16:0 in VO than FO (13.9\% and $13.4 \%$ vs. 11.6\%) (Table 4).

Table 4. Fat content and fatty acid composition ( $\%$ of total fatty acid content) of the liver in Mediterranean yellowtail fed the experimental diets ( $n=12$ per diet). Values are expressed as LS means.

\begin{tabular}{|c|c|c|c|c|c|}
\hline & \multicolumn{3}{|c|}{ Diet } & \multirow{2}{*}{$p$-Value } & \multirow{2}{*}{ RSD } \\
\hline & FO 100 & FO 25 & FO 0 & & \\
\hline Fat, \% WW & 26.6 & 30.1 & 25.7 & 0.721 & 9.296 \\
\hline \multicolumn{6}{|l|}{ Fatty acids, \% } \\
\hline $14: 0$ & $1.55^{\mathrm{c}}$ & $1.08^{b}$ & $0.79^{\mathrm{a}}$ & $<0.001$ & 0.129 \\
\hline $15: 0$ & $0.26^{c}$ & $0.15^{b}$ & $0.10^{\mathrm{a}}$ & $<0.001$ & 0.026 \\
\hline $16: 0$ & $13.88^{b}$ & $13.40^{b}$ & $11.57^{a}$ & $<0.001$ & 0.885 \\
\hline $17: 0$ & $0.49^{c}$ & $0.32^{b}$ & $0.24^{\mathrm{a}}$ & $<0.001$ & 0.037 \\
\hline $18: 0$ & $7.68^{b}$ & $7.82^{b}$ & $7.01^{\mathrm{a}}$ & 0.008 & 0.621 \\
\hline $20: 0$ & $0.31^{c}$ & $0.25^{b}$ & $0.21^{\mathrm{a}}$ & $<0.001$ & 0.014 \\
\hline $24: 0$ & 0.06 & 0.07 & 0.05 & 0.369 & 0.020 \\
\hline$\sum \mathrm{SFA}$ & $24.32^{b}$ & $23.26^{b}$ & $20.07^{a}$ & $<0.001$ & 1.317 \\
\hline $16: 1 \mathrm{n}-9$ & $3.26^{c}$ & $2.23^{b}$ & $1.64^{\mathrm{a}}$ & $<0.001$ & 0.153 \\
\hline $17: 1 \mathrm{n}-10$ & 0.26 & 0.18 & 0.19 & 0.323 & 0.139 \\
\hline $18: 1 \mathrm{n}-9$ & $32.02^{\mathrm{a}}$ & $35.18^{b}$ & $37.55^{c}$ & $<0.001$ & 1.371 \\
\hline $18: 1 \mathrm{n}-7$ & $7.30^{c}$ & $5.77^{\mathrm{b}}$ & $4.95^{\mathrm{a}}$ & $<0.001$ & 0.289 \\
\hline $20: 1 \mathrm{n}-9$ & $1.88^{\mathrm{b}}$ & $1.17^{\mathrm{a}}$ & $0.90^{\mathrm{a}}$ & $<0.001$ & 0.314 \\
\hline $22: 1 n-9$ & $0.37^{b}$ & $0.24^{\mathrm{a}}$ & $0.16^{\mathrm{a}}$ & $<0.001$ & 0.040 \\
\hline $24: 1 \mathrm{n}-9$ & $0.21^{b}$ & $0.12^{\mathrm{a}}$ & $0.09^{\mathrm{a}}$ & $<0.001$ & 0.063 \\
\hline$\Sigma$ MUFA & 45.29 & 44.90 & 45.47 & 0.613 & 1.431 \\
\hline $18: 2 \mathrm{n}-6$ & $15.23^{a}$ & $15.21^{\mathrm{a}}$ & $16.96^{b}$ & 0.002 & 1.10 \\
\hline $18: 3 n-6$ & 0.12 & 0.11 & 0.11 & 0.482 & 0.026 \\
\hline $20: 2 n-6$ & $1.23^{b}$ & $0.95^{\mathrm{a}}$ & $0.88^{\mathrm{a}}$ & $<0.001$ & 0.097 \\
\hline $20: 3 n-6$ & $0.21^{\mathrm{c}}$ & $0.13^{b}$ & $0.08^{a}$ & $<0.001$ & 0.021 \\
\hline $20: 4 n-6$ & $0.89^{c}$ & $0.53^{b}$ & $0.39^{a}$ & $<0.001$ & 0.097 \\
\hline $22: 2 n-6$ & $0.79^{c}$ & $0.42^{b}$ & $0.26^{\mathrm{a}}$ & $<0.001$ & 0.052 \\
\hline $22: 4$ n-6 & $0.26^{\mathrm{b}}$ & $0.08^{a}$ & $0.05^{\mathrm{a}}$ & $<0.001$ & 0.049 \\
\hline$\Sigma$ PUFA n-6 & $18.73^{b}$ & $17.43^{a}$ & $18.74^{b}$ & 0.036 & 1.207 \\
\hline $18: 3 n-3$ & $2.48^{\mathrm{a}}$ & $8.60^{b}$ & $11.27^{c}$ & $<0.001$ & 0.562 \\
\hline $20: 3 n-3$ & $0.36^{\mathrm{a}}$ & $0.81^{b}$ & $0.95^{c}$ & $<0.001$ & 0.117 \\
\hline $20: 5 n-3$ & $2.21^{\mathrm{c}}$ & $1.45^{\mathrm{b}}$ & $1.10^{\mathrm{a}}$ & $<0.001$ & 0.200 \\
\hline $22: 5 n-3$ & $2.35^{\mathrm{c}}$ & $1.35^{\mathrm{b}}$ & $0.83^{\mathrm{a}}$ & $<0.001$ & 0.199 \\
\hline $22: 6 n-3$ & $4.26^{\mathrm{b}}$ & $2.29^{\mathrm{a}}$ & $1.57^{\mathrm{a}}$ & $<0.001$ & 0.607 \\
\hline$\Sigma$ PUFA n-3 & $11.66^{\mathrm{a}}$ & $14.45^{b}$ & $15.72^{c}$ & $<0.001$ & 0.924 \\
\hline$\Sigma$ PUFA & $30.39^{a}$ & $31.84^{\mathrm{a}}$ & $34.46^{b}$ & $<0.001$ & 1.703 \\
\hline$\sum \mathrm{n}-6 / \Sigma \mathrm{n}-3$ & $1.62^{b}$ & $1.20^{\mathrm{a}}$ & $1.20^{\mathrm{a}}$ & $<0.001$ & 0.113 \\
\hline DHA/EPA & $1.93^{b}$ & $1.59^{a b}$ & $1.36^{\mathrm{a}}$ & $<0.001$ & 0.249 \\
\hline
\end{tabular}

FO 100 diet: Diet formulated with fish oil as lipid source; FO 25 diet: Diet in which fish oil was included at a content of 25\%; FO 0 diet: Diet in which fish oil was totally substituted with vegetable oil. Abbreviations: WW: Wet weight; RSD: Residual standard deviation; SFA: Saturated fatty acids; MUFA: Monounsaturated fatty acids; PUFA: Polyunsaturated fatty acids; DHA/EPA: 22:6 n-3/20:5 n-3. The FA < 0.1\% of the total FA (i.e., C12:0, C14:1, C22:0, and $\mathrm{C} 24: 0)$ are not given in the table. Different superscript letters indicate significant statistical differences among diets $(p \leq 0.05)$.

Moreover, the substitution of FO with $\mathrm{VO}$ in the diet decreased the relative content of C16:1 n-9 (3.26\% vs. $2.23 \%$ vs. $1.64 \%$ in FO 100 vs. FO 25 vs. FO 0 ) and C17:1 n-7 (7.30\% vs. 5.77\% vs. 4.95\%), whereas it increased that of C18:1 n-9 (32.0\% vs. $35.2 \%$ vs. $37.6 \%)(p<0.001)$. Thus, the proportion of the total MUFA (45.2\% on average) was not affected by the dietary treatment $(p>0.05)$. With regard to n-3 PUFA, the inclusion of less FO in the diet decreased the liver tissue's relative content of EPA (2.21\% vs. $1.45 \%$ vs. $1.10 \%$ in FO 100 vs. FO 25 vs. FO 0), C22:5 n-3 (2.35\% vs. $1.35 \%$ vs. $0.83 \%)$, and DHA $(4.26 \%$ vs. $2.29 \%$ and $1.57 \%)$, whereas it greatly increased $(p<0.001)$ its content of ALA $(2.48 \%$ vs. $8.60 \%$ vs. $11.3 \%$ ), and thus the total n-3 PUFA content. As for n-6 PUFA, the substitution of FO with VO decreased the AA proportion of liver tissue $(0.89 \%$ vs. $0.53 \%$ vs. $0.39 \% ; p<0.001)$ and increased that of LA (15.2\% and 15.2\% vs. $17.0 \%$ in FO 100 and FO 25 vs. FO $0 ; p<0.01)$. 


\subsection{Visceral Fat}

In the visceral fat, the total substitution of FO with VO in the diet significantly decreased ( $p<$ $0.001)$ the proportion of the total SFA $(23.6 \%$ and $23.8 \%$ vs. $22.5 \%$ of the total FA in FO 100 and FO 25 vs. FO 0) (Table 5). Moreover, the replacement of FO with VO decreased the C16:1 n-9 (4.07\% vs. 2.98\% vs. $2.48 \%$ in FO 100 vs. FO 25 vs. FO 0$)$ and $18: 1$ n-7 (4.89\% vs. $4.11 \%$ vs. $3.64 \%)$ proportions in the visceral fat, whereas it increased that of C18:1 n-9 (27.8\% vs. $30.0 \%$ vs. $32.6 \%)(p<0.001)$. With regard to n-3 PUFA, the inclusion of less FO in the diet decreased the EPA (3.68\% vs. 2.76\% vs. 2.07\%), C22:5 n-3 (1.82\% vs. $1.24 \%$ vs. $0.9 \%)$, and DHA (9.57\% vs. $5.72 \%$ vs. $4.01 \%)$ proportions in the visceral fat, and increased that of ALA therein (3.76\% vs. 9.44\% vs. $12.0 \%)(p<0.001)$, whereas the proportion of total n-3 PUFA (19.2\% on average) was not affected by diet $(p>0.05)$. As for $n-6$ PUFA, the substitution of FO with VO increased the LA relative content (14.6\% vs. $16.2 \%$ vs. $16.9 \%)$, which affected the total proportion of n-6 PUFA in this tissue $(17.4 \%$ vs. $17.9 \%$ vs. $18.2 \%)(p<0.001)$.

Table 5. Fat content and fatty acid composition (\% of total fatty acid content) of the visceral fat in Mediterranean yellowtails fed the experimental diets ( $n=12$ per diet). Values are expressed as LS means.

\begin{tabular}{|c|c|c|c|c|c|}
\hline & \multicolumn{3}{|c|}{ Diet } & \multirow{2}{*}{$p$-Value } & \multirow{2}{*}{ RSD } \\
\hline & FO 100 & FO 25 & FO 0 & & \\
\hline Fat, \% WW & 37.90 & 36.90 & 34.91 & 0.920 & 9.529 \\
\hline \multicolumn{6}{|l|}{ Fatty acids, \% } \\
\hline $14: 0$ & $2.55^{c}$ & $1.99^{b}$ & 1.64 & $<0.001$ & 0.094 \\
\hline $15: 0$ & $0.32^{c}$ & $0.22^{b}$ & $0.16^{\mathrm{a}}$ & $<0.001$ & 0.018 \\
\hline $16: 0$ & $14.57^{\mathrm{a}}$ & $15.00^{b}$ & $14.36^{\mathrm{a}}$ & $<0.001$ & 0.293 \\
\hline $17: 0$ & $0.44^{c}$ & $0.32^{b}$ & $0.26^{\mathrm{a}}$ & $<0.001$ & 0.023 \\
\hline $18: 0$ & $5.11^{\mathrm{a}}$ & $5.64^{b}$ & $5.46^{\mathrm{b}}$ & $<0.001$ & 0.207 \\
\hline $20: 0$ & $0.36^{\mathrm{c}}$ & $0.32^{b}$ & $0.29^{a}$ & $<0.001$ & 0.009 \\
\hline $22: 0$ & $0.14^{\mathrm{a}}$ & $0.18^{\mathrm{b}}$ & $0.19^{b}$ & 0.001 & 0.011 \\
\hline $24: 0$ & 0.10 & 0.11 & 0.12 & 0.307 & 0.026 \\
\hline$\Sigma$ SFA & $23.63^{b}$ & $23.80^{b}$ & $22.53^{a}$ & $<0.001$ & 0.415 \\
\hline $16: 1$ n-9 & $4.07^{c}$ & $2.98^{\mathrm{b}}$ & $2.48^{\mathrm{a}}$ & $<0.001$ & 0.184 \\
\hline $17: 1 \mathrm{n}-10$ & $0.37^{b}$ & $0.20^{\mathrm{a}}$ & $0.16^{\mathrm{a}}$ & $<0.001$ & 0.049 \\
\hline $18: 1 \mathrm{n}-9$ & $27.8^{a}$ & $30.0^{\mathrm{b}}$ & $32.6^{c}$ & $<0.001$ & 0.547 \\
\hline $18: 1 \mathrm{n}-7$ & $4.89^{c}$ & $4.11^{b}$ & $3.64^{\mathrm{a}}$ & $<0.001$ & 0.154 \\
\hline $20: 1 n-9$ & $1.96^{c}$ & $1.11^{\mathrm{b}}$ & $0.79^{a}$ & $<0.001$ & 0.116 \\
\hline $22: 1 \mathrm{n}-9$ & $0.40^{\mathrm{c}}$ & $0.22^{b}$ & $0.15^{\mathrm{a}}$ & $<0.001$ & 0.046 \\
\hline $24: 1 \mathrm{n}-9$ & $0.49^{c}$ & $0.30^{\mathrm{b}}$ & $0.23^{\mathrm{a}}$ & $<0.001$ & 0.038 \\
\hline$\Sigma$ MUFA & $39.95^{b}$ & $38.87^{\mathrm{a}}$ & $40.07^{b}$ & $<0.001$ & 0.495 \\
\hline $18: 2 n-6 c$ & $14.64^{\mathrm{a}}$ & $16.17^{b}$ & $16.89^{c}$ & $<0.001$ & 0.534 \\
\hline $18: 3 n-6$ & $0.14^{\mathrm{b}}$ & $0.12^{\mathrm{a}}$ & $0.12^{\mathrm{a}}$ & $<0.001$ & 0.003 \\
\hline $20: 2 n-6$ & $0.92^{c}$ & $0.64^{\mathrm{b}}$ & $0.48^{\mathrm{a}}$ & $<0.001$ & 0.043 \\
\hline $20: 3 n-6$ & $0.15^{b}$ & $0.07^{a b}$ & $0.06^{\mathrm{a}}$ & 0.023 & 0.075 \\
\hline $20: 4 n-6$ & $0.67^{c}$ & $0.43^{b}$ & $0.32^{\mathrm{a}}$ & $<0.001$ & 0.044 \\
\hline $22: 2 n-6$ & $0.52^{c}$ & $0.31^{b}$ & $0.26^{\mathrm{a}}$ & $<0.001$ & 0.044 \\
\hline $22: 4 n-6$ & $0.34^{c}$ & $0.18^{b}$ & $0.10^{\mathrm{a}}$ & $<0.001$ & 0.046 \\
\hline$\Sigma$ PUFA n-6 & $17.37^{\mathrm{a}}$ & $17.92^{a b}$ & $18.19^{b}$ & 0.003 & 0.534 \\
\hline $18: 3 n-3$ & $3.76^{\mathrm{a}}$ & $9.44^{\mathrm{b}}$ & $12.0^{\mathrm{c}}$ & $<0.001$ & 0.843 \\
\hline $20: 3 n-3$ & $0.22^{\mathrm{a}}$ & $0.26^{\mathrm{b}}$ & $0.28^{b}$ & $<0.001$ & 0.022 \\
\hline $20: 5 n-3$ & $3.68^{c}$ & $2.76^{b}$ & $2.07^{\mathrm{a}}$ & $<0.001$ & 0.150 \\
\hline $22: 5 n-3$ & $1.82^{c}$ & $1.24^{\mathrm{b}}$ & $0.90^{\mathrm{a}}$ & $<0.001$ & 0.010 \\
\hline $22: 6 n-3$ & $9.57^{c}$ & $5.72^{b}$ & $4.01^{\mathrm{a}}$ & $<0.001$ & 0.634 \\
\hline$\Sigma$ PUFA n-3 & 19.05 & 19.40 & 19.21 & 0.266 & 0.372 \\
\hline$\Sigma$ PUFA & $36.42^{a}$ & $37.33^{b}$ & $37.40^{\mathrm{b}}$ & 0.002 & 0.613 \\
\hline$\sum n-6 / \sum n-3$ & 0.91 & 0.92 & 0.95 & 0.104 & 0.035 \\
\hline DHA/EPA & $2.60^{b}$ & $2.07^{\mathrm{a}}$ & $1.94^{\mathrm{a}}$ & $<0.001$ & 0.153 \\
\hline
\end{tabular}

FO 100 diet: Diet formulated with fish oil as lipid source; FO 25 diet: Diet in which fish oil was included at a content of 25\%; FO 0 diet: Diet in which fish oil was totally substituted with vegetable oil. Abbreviations: WW: Wet weight; RSD: Residual standard deviation; SFA: Saturated fatty acids; MUFA: Monounsaturated fatty acids; PUFA: Polyunsaturated fatty acids; DHA/EPA: $22: 6$ n-3/20:5 n-3. The FA < 0.1\% of the total FA (i.e., C10:0, C12:0, C14:1) are not given in the table. Different superscript letters indicate significant statistical differences among diets $(p \leq 0.05)$. 


\subsection{Muscle}

In the red muscle, the replacement of FO with VO did not affect the proportion of total SFA ( $24.0 \%$ of the total FA on average) (Table 6). Among MUFA, the replacement of FO with VO increased the relative content of C18:1 n-9 (27.2\% vs. $29.0 \%$ vs. $31.8 \%$ in FO 100 vs. FO 25 vs. FO 0), whereas it decreased that of C18:1 n-7 (4.21\% vs. 3.65\% vs. 3.26\% in FO 100 vs. FO 25 vs. FO 0) and C20:1 n-9 $(1.91 \%$ vs. $1.05 \%$ vs. $0.74 \%)(p<0.001)$. For $n-3$ PUFA, the inclusion of less FO in the diet decreased the proportions of EPA (3.22\% vs. $2.60 \%$ vs. $2.14 \%)$, C22:5 n-3 (2.12\% vs. $1.58 \%$ vs. $1.29 \%)$, and DHA $(14.0 \%$ vs. $9.38 \%$ vs. $7.47 \%)$ in red muscle tissue, whereas it increased that of ALA (2.99\% vs. $7.68 \%$ vs. $9.84 \%)(p<0.001)$. In addition, the partial and total substitution of FO with VO in the diet increased the total n-6 PUFA content of red muscle $(14.7 \%$ vs. $16.0 \%$ and $16.7 \%)$ due to changes in the proportions of LA $(p<0.001)$.

Table 6. Fat content and fatty acid composition (\% of total fatty acid content) of the red muscle in Mediterranean yellowtails fed the experimental diets ( $n=12$ per diet). Values are expressed as LS means.

\begin{tabular}{|c|c|c|c|c|c|}
\hline & \multicolumn{3}{|c|}{ Diet } & \multirow{2}{*}{$p$-Value } & \multirow{2}{*}{ RSD } \\
\hline & FO 100 & FO 25 & FO 0 & & \\
\hline Fat, \% WW & 4.37 & 4.89 & 4.49 & 0.500 & 0.816 \\
\hline \multicolumn{6}{|l|}{ Fatty acids, \% } \\
\hline $14: 0$ & 1.81 & 1.81 & 1.26 & 0.105 & 0.602 \\
\hline $16: 0$ & 14.41 & 15.01 & 14.40 & 0.125 & 0.455 \\
\hline $17: 0$ & $0.44^{c}$ & $0.30^{b}$ & $0.24^{\mathrm{a}}$ & $<0.001$ & 0.035 \\
\hline $18: 0$ & $6.53^{a}$ & $6.91^{\mathrm{b}}$ & $6.83^{b}$ & $<0.001$ & 0.184 \\
\hline $20: 0$ & $0.38^{b}$ & $0.33^{a}$ & $0.32^{\mathrm{a}}$ & $<0.001$ & 0.017 \\
\hline 22:0 & $0.12^{\mathrm{a}}$ & $0.15^{b}$ & $0.16^{b}$ & $<0.001$ & 0.015 \\
\hline$\Sigma$ SFA & 23.88 & 24.65 & 23.33 & 0.061 & 0.769 \\
\hline $14: 1 \mathrm{n}-9$ & 0.11 & 0.12 & 0.10 & 0.956 & 0.100 \\
\hline $16: 1 \mathrm{n}-9$ & $3.14^{b}$ & $2.57^{a b}$ & $2.05^{\mathrm{a}}$ & 0.005 & 0.125 \\
\hline $17: 1 \mathrm{n}-10$ & $0.31^{b}$ & $0.21^{\mathrm{a}}$ & $0.16^{\mathrm{a}}$ & $<0.001$ & 0.011 \\
\hline $18: 1 \mathrm{n}-9$ & $27.21^{\mathrm{a}}$ & $29.04^{b}$ & $31.76^{c}$ & $<0.001$ & 0.509 \\
\hline $18: 1 \mathrm{n}-7$ & $4.21^{\mathrm{c}}$ & $3.65^{b}$ & $3.26^{\mathrm{a}}$ & $<0.001$ & 0.208 \\
\hline $20: 1 n-9$ & $1.91^{\mathrm{c}}$ & $1.05^{b}$ & $0.74^{\mathrm{a}}$ & $<0.001$ & 0.134 \\
\hline $22: 1 \mathrm{n}-9$ & $0.36^{\mathrm{b}}$ & $0.18^{a}$ & $0.13^{a}$ & $<0.001$ & 0.088 \\
\hline $24: 1 \mathrm{n}-9$ & $0.41^{\mathrm{c}}$ & $0.26^{\mathrm{b}}$ & $0.20^{\mathrm{a}}$ & $<0.001$ & 0.038 \\
\hline$\Sigma$ MUFA & $37.62^{a b}$ & $37.08^{a}$ & $38.37^{b}$ & 0.044 & 0.651 \\
\hline $18: 2 n-6 c$ & $13.05^{\mathrm{a}}$ & $14.83^{b}$ & $15.76^{c}$ & $<0.001$ & 0.552 \\
\hline $18: 3 n-6$ & 0.12 & 0.11 & 0.10 & 0.053 & 0.015 \\
\hline $20: 2 n-6$ & $0.78^{b}$ & $0.58^{\mathrm{a}}$ & $0.45^{\mathrm{a}}$ & $<0.001$ & 0.027 \\
\hline $20: 4 n-6$ & $0.91^{\mathrm{c}}$ & $0.65^{b}$ & $0.54^{\mathrm{a}}$ & $<0.001$ & 0.055 \\
\hline $22: 2 n-6$ & $0.40^{c}$ & $0.24^{b}$ & $0.16^{\mathrm{a}}$ & $<0.001$ & 0.031 \\
\hline $22: 4$ n-6 & $0.51^{\mathrm{c}}$ & $0.29^{b}$ & $0.21^{\mathrm{a}}$ & $<0.001$ & 0.040 \\
\hline$\Sigma$ PUFA n-6 & $14.70^{\mathrm{a}}$ & $15.95^{b}$ & $16.68^{b}$ & $<0.001$ & 0.513 \\
\hline $18: 3 n-3$ & $2.99^{a}$ & $7.68^{b}$ & $9.84^{c}$ & $<0.001$ & 0.705 \\
\hline $20: 3 n-3$ & $0.20^{\mathrm{a}}$ & $0.25^{b}$ & $0.27^{b}$ & $<0.001$ & 0.021 \\
\hline $20: 5 n-3$ & $3.22^{c}$ & $2.60^{b}$ & $2.14^{\mathrm{a}}$ & $<0.001$ & 0.116 \\
\hline $22: 5 n-3$ & $2.12^{\mathrm{c}}$ & $1.58^{b}$ & $1.29^{\mathrm{a}}$ & $<0.001$ & 0.155 \\
\hline $22: 6 n-3$ & $14.00^{\mathrm{C}}$ & $9.38^{b}$ & $7.47^{\mathrm{a}}$ & $<0.001$ & 0.946 \\
\hline$\sum$ PUFA n-3 & $22.56^{b}$ & $21.50^{a b}$ & $21.01^{\mathrm{a}}$ & 0.036 & 0.884 \\
\hline$\Sigma$ PUFA & 38.50 & 38.27 & 38.30 & 0.925 & 0.881 \\
\hline$\sum n-6 / \sum n-3$ & $1.54^{\mathrm{b}}$ & $1.35^{\mathrm{a}}$ & $1.26^{\mathrm{a}}$ & $<0.001$ & 0.083 \\
\hline DHA/EPA & $4.34^{\mathrm{b}}$ & $3.61^{\mathrm{a}}$ & $3.49^{\mathrm{a}}$ & 0.001 & 0.280 \\
\hline
\end{tabular}

FO 100 diet: Diet formulated with fish oil as lipid source; FO 25 diet: Diet in which fish oil was included at a content of $25 \%$; FO 0 diet: Diet in which fish oil was totally substituted with vegetable oil. Abbreviations: WW: Wet weight; RSD: Residual standard deviation; SFA: Saturated fatty acids; MUFA: Monounsaturated fatty acids; PUFA: Polyunsaturated fatty acids; DHA/EPA: 22:6 n-3/20:5 n-3. The FA < 0.1\% of the total FA (i.e., C12:0, C15:0, C20:3 n-6, and C24:0) are not given in the table. Different superscript letters indicate significant statistical differences among diets $(p \leq 0.05)$.

In the white muscle, the substitution of $\mathrm{FO}$ with $\mathrm{VO}$ in the diet decreased the proportion of total SFA (24.0\% and $23.8 \%$ vs. $22.6 \%$ in FO 100 vs. FO 25 vs. FO 0$)$ and increased that of C18:1 n-9 (27.6\% vs. $29.0 \%$ vs. $31.7 \%)$; this also decreased the relative content of C16:1 n-9 (3.78\% vs. $2.90 \%$ vs. $2.36 \%)$ 
and C20:1 n-9 (1.76\% vs. $1.09 \%$ vs. $0.76 \%$ ) in white muscle tissue (Table 7$)$. For n-3 PUFA, the inclusion of less FO in the diet decreased the EPA (3.41\% vs. $2.87 \%$ vs. $2.26 \%)$, C22:5 n-3 (1.71\% vs. $1.38 \%$ vs. $1.05 \%)$, and DHA (11.6\% vs. $8.59 \%$ vs. $6.38 \%$ ) content in white muscle tissue, whereas it increased the ALA content $(3.76 \%$ vs. $9.44 \%$ vs. $12.0 \%)(p<0.001)$. Nevertheless, the proportion of total n-3 PUFA $(21.0 \%$ on average) was not affected $(p>0.05)$ by dietary treatment. Finally, the LA relative content in the white muscle was increased by this treatment (14.2\% vs. $15.6 \%$ and $16.5 \%)$, which affected the total n-6 PUFA content $(15.6 \%$ vs. $16.7 \%$ vs. $17.3 \%)(p<0.001)$.

Table 7. Fat content and fatty acid composition (\% of total fatty acid content) of the white muscle in Mediterranean yellowtails fed the experimental diets $(n=12$ per diet). Values are expressed as LS means.

\begin{tabular}{|c|c|c|c|c|c|}
\hline & \multicolumn{3}{|c|}{ Diet } & \multirow{2}{*}{$p$-Value } & \multirow{2}{*}{ RSD } \\
\hline & FO 100 & FO 25 & FO 0 & & \\
\hline Fat, \% WW & 5.84 & 5.94 & 6.03 & 0.941 & 0.770 \\
\hline \multicolumn{6}{|l|}{ Fatty acids, \% } \\
\hline $14: 0$ & $2.28^{c}$ & $1.80^{\mathrm{b}}$ & $1.47^{\mathrm{a}}$ & $<0.001$ & 0.132 \\
\hline $16: 0$ & $14.97^{\mathrm{b}}$ & $14.78^{b}$ & $14.22^{\mathrm{a}}$ & 0.035 & 0.366 \\
\hline $17: 0$ & $0.39^{c}$ & $0.30^{b}$ & $0.23^{\mathrm{a}}$ & $<0.001$ & 0.037 \\
\hline 18:0 & 5.89 & 6.21 & 6.13 & 0.050 & 0.171 \\
\hline $20: 0$ & $0.36^{c}$ & $0.33^{b}$ & $0.32^{\mathrm{a}}$ & $<0.001$ & 0.013 \\
\hline $22: 0$ & $0.12^{\mathrm{a}}$ & $0.15^{b}$ & $0.16^{b}$ & 0.020 & 0.032 \\
\hline$\Sigma$ SFA & $23.94^{b}$ & $23.80^{b}$ & $22.63^{a}$ & 0.009 & 0.494 \\
\hline $14: 1 \mathrm{n}-9$ & $0.28^{c}$ & $0.22^{b}$ & $0.15^{\mathrm{a}}$ & $<0.001$ & 0.038 \\
\hline $16: 1 \mathrm{n}-9$ & $3.78^{c}$ & $2.90^{b}$ & $2.36^{\mathrm{a}}$ & $<0.001$ & 0.200 \\
\hline $17: 1 \mathrm{n}-10$ & $0.33^{c}$ & $0.22^{b}$ & $0.17^{\mathrm{a}}$ & $<0.001$ & 0.026 \\
\hline $18: 1 \mathrm{n}-9$ & $27.55^{\mathrm{a}}$ & $29.02^{b}$ & $31.72^{c}$ & $<0.001$ & 0.759 \\
\hline $18: 1 \mathrm{n}-7$ & $4.15^{c}$ & $3.56^{\mathrm{b}}$ & $3.20^{\mathrm{a}}$ & $<0.001$ & 0.165 \\
\hline $20: 1 n-9$ & $1.76^{c}$ & $1.09^{b}$ & $0.76^{\mathrm{a}}$ & $<0.001$ & 0.175 \\
\hline $22: 1 n-9$ & $0.29^{c}$ & $0.19^{b}$ & $0.12^{\mathrm{a}}$ & $<0.001$ & 0.045 \\
\hline $24: 1 \mathrm{n}-9$ & $0.35^{c}$ & $0.27^{\mathrm{b}}$ & $0.19^{a}$ & $<0.001$ & 0.048 \\
\hline$\Sigma$ MUFA & 38.63 & 37.50 & 38.63 & 0.050 & 0.615 \\
\hline $18: 2 n-6 c$ & $14.15^{\mathrm{a}}$ & $15.59^{b}$ & $16.46^{b}$ & $<0.001$ & 0.552 \\
\hline $18: 3 n-6$ & $0.14^{b}$ & $0.13^{\mathrm{a}}$ & $0.12^{\mathrm{a}}$ & 0.001 & 0.009 \\
\hline $20: 2 n-6$ & $0.86^{\mathrm{c}}$ & $0.63^{b}$ & $0.49^{a}$ & $<0.001$ & 0.059 \\
\hline $20: 4 n-6$ & $0.79^{c}$ & $0.61^{b}$ & $0.48^{\mathrm{a}}$ & $<0.001$ & 0.076 \\
\hline $22: 2 n-6$ & $0.42^{\mathrm{c}}$ & $0.28^{b}$ & $0.19^{a}$ & $<0.001$ & 0.037 \\
\hline $22: 4 n-6$ & $0.41^{c}$ & $0.26^{\mathrm{b}}$ & $0.18^{\mathrm{a}}$ & $<0.001$ & 0.052 \\
\hline$\Sigma$ PUFA n-6 & $16.45^{\mathrm{a}}$ & $17.20^{a b}$ & $17.80^{b}$ & 0.001 & 0.493 \\
\hline $18: 3 n-3$ & $3.93^{\mathrm{a}}$ & $8.25^{b}$ & $10.84^{c}$ & $<0.001$ & 1.141 \\
\hline $20: 3 n-3$ & $0.20^{\mathrm{a}}$ & $0.23^{b}$ & $0.25^{c}$ & $<0.001$ & 0.019 \\
\hline $20: 5 n-3$ & $3.41^{\mathrm{c}}$ & $2.87^{\mathrm{b}}$ & $2.26^{\mathrm{a}}$ & $<0.001$ & 0.198 \\
\hline $22: 5 n-3$ & $1.71^{\mathrm{c}}$ & $1.38^{\mathrm{b}}$ & $1.05^{\mathrm{a}}$ & $<0.001$ & 0.136 \\
\hline $22: 6 n-3$ & $11.63^{c}$ & $8.59^{b}$ & $6.38^{a}$ & $<0.001$ & 1.196 \\
\hline$\Sigma$ PUFA n-3 & 20.60 & 21.21 & 20.77 & 0.830 & 0.773 \\
\hline$\Sigma$ PUFA & 37.48 & 38.70 & 38.74 & 0.500 & 0.825 \\
\hline$\sum n-6 / \sum n-3$ & 0.80 & 0.81 & 0.86 & 0.086 & 0.069 \\
\hline DHA/EPA & $3.43^{b}$ & $2.95^{\mathrm{a}}$ & $2.82^{\mathrm{a}}$ & 0.019 & 0.234 \\
\hline
\end{tabular}

FO 100 diet: Diet formulated with fish oil as lipid source; FO 25 diet: Diet in which fish oil was included at a content of 25\%; FO 0 diet: Diet in which fish oil was totally substituted with vegetable oil. Abbreviations: WW: Wet weight; RSD: Residual standard deviation; SFA: Saturated fatty acids; MUFA: Monounsaturated fatty acids; PUFA: Polyunsaturated fatty acids; DHA/EPA: 22:6 n-3/20:5 n-3. The FA < 0.1\% of the total FA (i.e., C12:0, C15:0, C20:3 n-6, and C24:0) are not given in the table. Different superscript letters indicate significant statistical differences among diets $(p \leq 0.05)$.

\section{Discussion}

Successful growth performance may be achieved in fish fed with diets containing low levels of FO as long as their minimum EFA requirements are met [39]. In the larval stages, DHA plays a key role in promoting the development of neural membranes and eyes [40], improving growth, vitality, and survival [1,14,41], and preventing swimming disorders such as spinning and disorientation [41]. The accumulation of DHA in the brain during fish development has been measured in several marine species [14], which also show very low rates of DHA biosynthesis. Thus, any DHA deficiency during 
larval development will have serious consequences for the successful performance of fish larvae [14]. Moreover, DHA is essential for the development of schooling behaviour in the Mediterranean yellowtail [42-44]. Data in the published literature show that larvae (aged 3-7 days after hatching (dah)) of Seriola dumerili fed with rotifers [1] require a supply of DAH equal to $1.5 \%$ of the dry matter $(\mathrm{DM})$ in their diet. Larvae (7 $\mathrm{mm}$ in length) of the related Japanese amberjack (S. quinqueradiata Temminck and Schlegel, 1845) fed with Artemia required a diet containing 3.9\% of n-3 HUFA $(2.5 \%$ and $1.3 \%$ DM of EPA and DHA, respectively) in a previous study [41]. Further, in S. rivoliana Valenciennes, 1833 larvae (aged 30 to 50 dah) had higher survival rates and better stress resistance when fed microdiets containing 3.2\% DM of DHA [45].

In this experiment, the dietary treatments tested provided a minimum n-3 HUFA supply of $0.75 \%$ DM, which should be sufficient to meet the EFA requirements of most marine species (minimum value: $0.5 \% \mathrm{DM}$ in juveniles and subadults of marine species [39]). Under different conditions, the total EFA requirements for juveniles (39 to $387 \mathrm{~g}$ of live weight in a 154-day feeding trial) of Mediterranean yellowtail have been estimated to be 1.2\% DM [11]. In fact, juvenile fish, although they still need EFA, are likely to require lower levels of EPA and DHA in their diet than those needed in the larval stage. Nevertheless, dietary DHA deprivation in juveniles of pelagic marine species, such as carangids and tunids, can be particularly deleterious because of their fast growth rates [14], especially when they are fed diets containing low levels of FO.

During the grow-out phase, EFA deficiencies may reduce fish growth. In this regard, a substitution of $60 \%$ of the FO with $\mathrm{VO}$ in the diet is considered acceptable [46]. For carangid species, the growth performance of Japanese yellowtail (S. quinqueradiata) (average initial weight: $252 \mathrm{~g}$; final weight $412 \mathrm{~g}$ ) was not affected by the full replacement of FO with olive oil in a previous short-term feeding trial (40 days) [47]. On the contrary, yellowtail kingfish (S. lalandi Valenciennes, 1833) showed impaired growth rates when FO was totally substituted with canola or sunflower oil in their diet during a five-week-long feeding trial (with a weight change from 96 to $260 \mathrm{~g}$ ) [47].

In the present study of $S$. dumerili (grown from 176 to $417 \mathrm{~g}$ of live weight, with 109 days of feeding), diets containing only $\mathrm{VO}$ as the lipid source had no detrimental impacts on the growth performance of these fish. Nevertheless, the survival rate was lower in fish fed diets without fish oil compared with those in fish fed diets containing $100 \%$ (FO 100) or $25 \%$ (FO 25) fish oil.

Indeed, Monge-Ortiz et al. [11] reported that diets including at least $525 \mathrm{~g} \mathrm{~kg}^{-1}$ of fish meal (FM) are likely to supply enough LC-PUFA to meet the needs of fish, even with the complete substitution of FO (with fish reaching a final weight of $397 \mathrm{~g}$ ). In fact, FM usually contains up to $8 \%-15 \%$ DM of crude lipid, 30\%-35\% of which is composed of n-3 LC-PUFA [19]. In the present study, the experimental diets contained $350 \mathrm{~g} \mathrm{~kg}^{-1}$ of FM, which likely met the FA requirements of the studied fish during the grow-out phase.

The present study measured fat storage in different tissues, including the muscles, brain, liver, and visceral fat. Indeed, the locations of fat storage differ within and between fish species $[15,48,49]$. In a previous study [50], a high lipid content (53\% DM) was found in the liver of farmed S. dumerili, which was consistent with that recorded in the present study $(60 \% \mathrm{DM})$ and higher than the fat content of the muscle tissue (12\% DM) [50].

The replacement of FO with VO in fish diets may lead to the accumulation of fat in the fish liver, generating a fatty liver syndrome, which may be the result of inefficient nutrient utilisation and increased rates of lipid peroxidation [51,52]. Nevertheless, we did not find differences in the liver fat content of the tested fish, even when they were fed with diets containing only VO as the lipid source, which was consistent with the findings of previous studies done on European seabass [53], gilthead sea bream [54], and turbot (Psetta maxima (L.; 1758)) [55].

Regardless of whether FO replacement affects fish growth and the lipid content of their tissues, its impact on fatty acid composition will vary depending on the dietary lipid content and source, as well as on the tissues considered [19]. The fatty acid signatures of fish tissues are closely related to their dietary FA composition [19]. Complete or partial FO replacement with VO blends is known to affect 
the FA compositions of muscles, fish organs, and fat storage tissues [19]. However, the magnitude of the changes in FA signatures varies among different fish species and tissues [56-58].

The FA signature of several wild and farmed fish was previously measured in muscle and liver tissues, but to our knowledge, few studies have investigated the FA signatures of other fatty tissues, such as those of the visceral fat and brain. Specifically, in wild and farmed Mediterranean yellowtail, the FA composition has been analysed in the muscles, liver, ovary $[10,11,50,59,60]$, and eggs [61]. Other studies have been performed in other Seriola species, such as S. lalandi [47,62,63], $S$. quinqueradiata [64,65], S. dorsalis (Gill, 1863) [66,67], and S. rivoliana [45], which mainly focused on the FA composition of muscle tissues.

In the liver of Mediterranean yellowtail, we found a high proportion of MUFA and a low proportion of SFA, likely because their C16:0, C18:0, and C22:0 content was sufficient to maintain or even exceed the requirements of liver metabolic functions. In the brain and visceral fat, PUFA were highly represented (representing on average $37.9 \%$ and $37.1 \%$ of the total FA content in the brain and visceral fat, respectively). In fact, PUFA (especially C18 FA, such as LA and ALA) are generally stored in non-lipogenic tissues, especially the visceral fat, and are likely used as metabolic substrates for $\beta$-oxidation $[58,68,69]$. Moreover, the brain contained a high proportion of DHA (on average $23.0 \%$ of the total FA), which is known to regulate membrane fluidity, the blood-brain barrier, and the activities of certain enzymes, such as ionic channel proteins and nerve growth factors, both in mammals $[70,71]$ and fish $[1,14,45]$. In salmonids, Atlantic cod, and flatfishes, DHA is also present at high levels in the brain $[12,15,72]$, which agrees with our findings.

Consistent with other studies [56,73,74], the muscle, liver, and visceral fat FA signatures of Mediterranean yellowtail found in our study reflected the dietary FA profiles of these fish, with the FA signatures of these tissues thus showing a low robustness to changes in the dietary lipid sources from FO to VO. In contrast, the brain FA signature was less strongly affected by the dietary FA composition, whereas only ALA, EPA, and DHA changed. Nevertheless, in European seabass, brain lipids appeared to be sensitive to dietary lipid inputs [75]. On the contrary, a more recent study in juvenile European seabass fed n-3 LC-PUFA-deficient diets showed that polar lipids in their neural tissues had the highest capacity to regulate and preserve their DHA content [76]. In the present study, fish fed the diet with $100 \%$ VO showed a 10\% lower DHA content in the brain than those fed diets with fish oil (FO 100 and FO 25) and a lower survival, which could have been related to some effects of EFA deficiency in them. In contrast, the administration of the FO 25 diet did not decrease the DHA proportion in the brain, which suggests that the substitution of $75 \%$ of the FO in the diet with VO could be suitable for use in diets for rearing Mediterranean yellowtail juveniles from 176 to $417 \mathrm{~g}$ of live weight. Further studies are necessary to confirm these results over longer feeding periods.

\section{Conclusions}

This study provided new findings on the FA signatures in different tissues of Seriola dumerili fed diets with decreasing levels of FO included in them. The FA composition of the diet had a strong effect on the FA compositions of muscle, liver, and visceral fat tissues. The brain had a FA signature that was more robust to dietary changes, whereas only some EFA (EPA and DHA) decreased when fish oil was totally replaced by vegetable oil.

Author Contributions: Conceptualization, S.M.-L.; A.T.-V.; and M.J.-C.; Formal analysis, F.B. and M.C.M.S.; Investigation, F.B. and M.C.M.S.; Data curation, A.T.-V.; F.B.; and A.T.; Writing-original draft preparation, F.B.; A.T.; A.T.-V.; and S.M.-L.; Writing-review and editing, F.B.; A.T.; A.T.-V.; S.M.-L.; and M.J.-C. All authors have read and agreed to the published version of the manuscript.

Funding: The Ph.D. grant held by Francesco Bordignon is funded by the ECCEAQUA project (MIUR; CUP: C26C18000030004).

Acknowledgments: The authors gratefully acknowledge V. J. Moya Salvador and L. Ródenas for their technical support during chemical analyses of fats and fatty acids.

Conflicts of Interest: The authors declare no conflict of interest. 


\section{References}

1. Matsunari, H.; Hashimoto, H.; Oda, K.; Masuda, Y.; Imaizumi, H.; Teruya, K.; Furuita, H.; Yamamoto, T.; Hamada, K.; Mushiake, K. Effects of docosahexaenoic acid on growth, survival and swim bladder inflation of larval amberjack (Seriola dumerili, Risso). Aquac. Res. 2013, 44, 1696-1705. [CrossRef]

2. Grau, A.; Riera, F.; Carbonell, E. Some protozoan and metazoan parasites of the amberjack from the Balearic Sea (western Mediterranean). Aquac. Int. 1999, 7, 307-317. [CrossRef]

3. Andaloro, F.; Pipitone, C. Food and feeding habits of the amberjack, Seriola dumerili in the Central Mediterranean Sea during the spawning season. Cah. Biol. Mar. 1997, 38, 91-96.

4. Sicuro, B.; Luzzana, U. The State of Seriola spp. other than yellowtail (S. quinqueradiata) farming in the World. Rev. Fish. Sci. Aquac. 2016, 24, 314-325. [CrossRef]

5. Mazzola, A.; Favaloro, E.; Sarà, G. Cultivation of the Mediterranean amberjack, Seriola dumerili (Risso, 1810), in submerged cages in the Western Mediterranean Sea. Aquaculture 2000, 181, 257-268. [CrossRef]

6. Jover, M.; García-Gómez, A.; Tomás, A.; De La Gándara, F.; Pérez, L. Growth of Mediterranean yellowtail (Seriola dumerili) fed extruded diets containing different levels of protein and lipid. Aquaculture 1999, 179, 25-33. [CrossRef]

7. Takakuwa, F.; Fukada, H.; Hosokawa, H.; Masumoto, T. Optimum digestible protein and energy levels and ratio for greater amberjack Seriola dumerili (Risso) fingerling. Aquac. Res. 2006, 37, 1532-1539. [CrossRef]

8. Vidal, A.T.; De La Gándara, F.; Gómez, A.G.; Cerdá, M.J. Effect of the protein/energy ratio on the growth of Mediterranean yellowtail (Seriola dumerili). Aquac. Res. 2008, 39, 1141-1148. [CrossRef]

9. Papadakis, I.E.; Chatzifotis, S.; Divanach, P.; Kentouri, M. Weaning of greater amberjack (Seriola dumerili Risso 1810) juveniles from moist to dry pellet. Aquac. Int. 2008, 16, 13-25. [CrossRef]

10. Haouas, W.G.; Zayene, N.; Guerbej, H.; Hammami, M.; Achour, L. Fatty acids distribution in different tissues of wild and reared Seriola dumerili. Int. J. Food Sci. Technol. 2010, 45, 1478-1485. [CrossRef]

11. Monge-Ortiz, R.; Tomás-Vidal, A.; Rodriguez-Barreto, D.; Martínez-Llorens, S.; Pérez, J.A.; Jover-Cerdá, M.; Lorenzo, A. Replacement of fish oil with vegetable oil blends in feeds for greater amberjack (Seriola dumerili) juveniles: Effect on growth performance, feed efficiency, tissue fatty acid composition and flesh nutritional value. Aquac. Nutr. 2018, 24, 605-615. [CrossRef]

12. Mourente, G.; Tocher, D.R.; Sargent, J.R. Specific accumulation of docosahexaenoic acid (22:6n-3) in brain lipids during development of juvenile turbot Scophthalmus maximus L. Lipids 1991, 26, 871-877. [CrossRef]

13. Sargent, J.; Bell, G.; McEvoy, L.; Tocher, D.; Estevez, A. Recent developments in the essential fatty acid nutrition of fish. Aquaculture 1999, 77, 191-199. [CrossRef]

14. Mourente, G. Accumulation of DHA (docosahexaenoic acid; 22:6n-3) in larval and juvenile fish brain. In Proceedings of the 26th Annual Larval Fish Conference, Os, Norway, 22-26 July 2002; Brownman, H., Skiftesvik, A.B., Eds.; Institute of Marine Research: Bergen, Norway, 2003; pp. 239-248.

15. Tocher, D.R.; Harvie, D.G. Fatty acid compositions of the major phosphoglycerides from fish neural tissues; (n-3) and (n-6) polyunsaturated fatty acids in rainbow trout (Salmo gairdneri) and cod (Gadus morhua) brains and retinas. Fish. Physiol. Biochem. 1988, 5, 229-239. [CrossRef] [PubMed]

16. Bell, J.G.; Castell, J.D.; Tocher, D.R.; MacDonald, F.M.; Sargent, J.R. Effects of different dietary arachidonic acid: Docosahexaenoic acid ratios on phospholipid fatty acid compositions and prostaglandin production in juvenile turbot (Scophthalmus maximus). Fish. Physiol. Biochem. 1995, 14, 139-151. [CrossRef] [PubMed]

17. Sargent, J.R.; McEvoy, L.A.; Bell, J.G. Requirements, presentation and sources of polyunsaturated fatty acids in marine fish larval feeds. Aquaculture 1997, 155, 117-127. [CrossRef]

18. Tocher, D.R.; Ghioni, C. Fatty acid metabolism in marine fish: Low activity of fatty acyl delta5 desaturation in gilthead sea bream (Sparus aurata) cells. Lipids 1999, 34, 433-440. [CrossRef]

19. Turchini, G.M.; Torstensen, B.E.; Ng, W.K. Fish oil replacement in finfish nutrition. Rev. Aquac. 2009, 1, 10-57. [CrossRef]

20. Iverson, S.J.; Field, C.; Bowen, W.D.; Blanchard, W. Quantitative fatty acid signature analysis: A new method. Ecol. Monogr. 2004, 74, 211-235. [CrossRef]

21. Sargent, J.R.; Bell, J.G.; Bell, M.V.; Henderson, R.J.; Tocher, D.R. The metabolism of phospholipids and polyunsaturated fatty acids in fish. In Aquaculture: Fundamental and Applied Research; Lahlou, B., Vitiello, P., Eds.; Coastal and Estuarine Studies; American Geophysical Union: Washington, DC, USA, 1993; Volume 43, pp. 103-124. 
22. Henderson, J.R.; Tocher, D.R. The lipid composition and biochemistry of freshwater fish. Prog. Lipid Res. 1987, 26, 281-347. [CrossRef]

23. Furuita, H.; Takeuchi, T.; Uematsu, K. Effects of eicosapentaenoic and docosahexaenoic acids on growth, survival and brain development of larval Japanese flounder (Paralichthys olivaceus). Aquaculture 1998, 161, 269-279. [CrossRef]

24. Anderson, G.J.; Connoro, W.E.; Corliss, J.D. Docosahexaenoic acid is the preferred dietary n-3 fatty acid for the development of the brain and retina. Pediatr. Res. 1990, 27, 89-97. [CrossRef] [PubMed]

25. Bianconi, S.; Santillán, M.E.; del Rosario Solís, M.; Martini, A.C.; Ponzio, M.F.; Vincenti, L.M.; Schiöth, H.B.; Carlini, V.P.; Stutz, G. Effects of dietary omega-3 PUFAs on growth and development: Somatic, neurobiological and reproductive functions in a murine model. J. Nutr. Biochem. 2018, 61, 82-90. [CrossRef] [PubMed]

26. Bergé, J.P.; Barnathan, G. Fatty acids from lipids of marine organisms: Molecular biodiversity, roles as biomarkers, biologically active compounds, and economical aspects. Adv. Biochem. Eng. Biotechnol. 2005, 96, 49-125.

27. Thiemann, G.W. Using fatty acid signatures to study bear foraging: Technical considerations and future applications. Ursus 2008, 19, 59-72. [CrossRef]

28. Kaushik, S.J.; Corraze, G.; Radunz-Neto, J.; Larroquet, L.; Dumas, J. Fatty acid profiles of wild brown trout and Atlantic salmon juveniles in the Nivelle basin. J. Fish. Biol. 2006, 68, 1376-1387. [CrossRef]

29. Stowasser, G.; McAllen, R.; Pierce, G.J.; Collins, M.A.; Moffat, C.F.; Priede, I.G.; Pond, D. Trophic position of deep-sea fish-Assessment through fatty acid and stable isotope analyses. Deep Res. Part I Oceanogr. Res. Pap. 2009, 56, 812-826. [CrossRef]

30. Budge, S.M.; Penney, S.N.; Lall, S.P. Estimating diets of Atlantic salmon (Salmo salar) using fatty acid signature analyses; validation with controlled feeding studies. Can. J. Fish. Aquat. Sci. 2012, 69, 1033-1046. [CrossRef]

31. Magnone, L.; Bessonart, M.; Rocamora, M.; Gadea, J.; Salhi, M. Diet estimation of Paralichthys orbignyanus in a coastal lagoon via quantitative fatty acid signature analysis. J. Exp. Mar. Biol. Ecol. 2015, 462, 36-49. [CrossRef]

32. Happel, A.; Stratton, L.; Pattridge, R.; Rinchard, J.; Czesny, S. Fatty-acid profiles of juvenile lake trout reflect experimental diets consisting of natural prey. Freshw. Biol. 2016, 61, 1466-1476. [CrossRef]

33. Benedito-Palos, L.; Navarro, J.C.; Kaushik, S.; Pérez-Sánchez, J. Tissue-specific robustness of fatty acid signatures in cultured gilthead sea bream (Sparus aurata L.) fed practical diets with a combined high replacement of fish meal and fish oil. J. Anim. Sci. 2010, 88, 1759-1770. [CrossRef]

34. AOAC. International Official Methods of Analysis of AOAC International, 17th ed.; Association of Official Analytical Chemists: Arlington, VA, USA, 1990.

35. Brouwer, E. Report of Sub-Committee on Constants and Factors. In Proceedings of the 3rd Symposium on Energy Metabolism; Blaxter, K.L., Ed.; London Academic Press: London, UK, 1965; pp. 441-443.

36. Folch, J.; Lees, M.; Sloane Stanley, G.H. A simple method for the isolation and purification of total lipids from animal tissues. J. Biol. Chem. 1957, 226, 497-509.

37. O'Fallon, J.V.; Busboom, J.R.; Nelson, M.L.; Gaskins, C.T. A direct method for fatty acid methyl ester synthesis: Application to wet meat tissues, oils, and feedstuffs. J. Anim. Sci. 2007, 85, 1511-1521. [CrossRef]

38. SAS (Statistical Analysis System Institute, Inc.). SAS/STAT(R) 9.3 User's Guide, 3rd ed.; SAS Institute: Cary, NC, USA, 2013; Available online: https:/support.sas.com/documentation/cdl/en/statug/63962/HTML/default/ viewer.htm\#titlepage.htm (accessed on 1 May 2019).

39. Tocher, D.R. Fatty acid requirements in ontogeny of marine and freshwater fish. Aquac. Res. 2010, 41, 717-732. [CrossRef]

40. Ishizaki, Y.; Masuda, R.; Uematsu, K.; Shimizu, K.; Arimoto, M.; Takeuchi, T. The effect of dietary docosahexaenoic acid on schooling behaviour and brain development in larval yellowtail. J. Fish. Biol. 2001, 58, 1691-1703. [CrossRef]

41. Furuita, H.; Takeuchi, T.; Watanabe, T.; Fujimoto, H.; Sekiya, S.; Imaizumi, K. Requirements of larval yellowtail for eicosapentanoic acid, docosahaenoic acid, and n-3 highly unsaturated fatty acid. Fish. Sci. 1996, 62, 372-379. [CrossRef]

42. Masuda, R.; Takeuchi, T.; Tsukamoto, K.; Sato, H.; Shimizu, K.; Imaizumi, K. Incorporation of dietary docosahexaenoic acid into the central nervous system of the yellowtail Seriola quinqueradiata. Brain Behav. Evol. 1999, 53, 173-179. [CrossRef] 
43. Masuda, R.; Takeuchi, T.; Takeuchi, T.; Tsukamoto, K.; Tsukamoto, K.; Ishizaki, Y.; Kanematsu, M.; Imaizum, K. Critical involvement of dietary docosahexaenoic acid in the ontogeny of schooling behaviour in the yellowtail. J. Fish. Biol. 1998, 53, 471-484. [CrossRef]

44. Masuda, R.; Tsukamoto, K. School formation and concurrent developmental changes in carangid fish with reference to dietary conditions. Environ. Biol. Fish. 1999, 56, 243-252. [CrossRef]

45. Mesa-Rodriguez, A.; Hernández-Cruz, C.M.; Betancor, M.B.; Fernández-Palacios, H.; Izquierdo, M.S.; Roo, J. Effect of increasing docosahexaenoic acid content in weaning diets on survival, growth and skeletal anomalies of longfin yellowtail (Seriola rivoliana, Valenciennes 1833). Aquac. Res. 2018, 49, 1200-1209. [CrossRef]

46. Nasopoulou, C.; Zabetakis, I. Benefits of fish oil replacement by plant originated oils in compounded fish feeds. A review. LWT-Food Sci. Technol. 2012, 47, 217-224. [CrossRef]

47. Bowyer, J.N.; Qin, J.G.; Smullen, R.P.; Stone, D.A.J. Replacement of fish oil by poultry oil and canola oil in yellowtail kingfish (Seriola lalandi) at optimal and suboptimal temperatures. Aquaculture 2012, 356-357, 211-222. [CrossRef]

48. Bell, J.G.; Strachan, F.; Good, J.E.; Tocher, D.R. Effect of dietary echium oil on growth, fatty acid composition and metabolism, gill prostaglandin production and macrophage activity in Atlantic cod (Gadus morhua L.). Aquac. Res. 2006, 37, 606-617. [CrossRef]

49. Stoknes, I.S.; Økland, H.M.W.; Falch, E.; Synnes, M. Fatty acid and lipid class composition in eyes and brain from teleosts and elasmobranchs. Comp. Biochem. Physiol.-B Biochem. Mol. Biol. 2004, 138, 183-191. [CrossRef]

50. Rodríguez-Barreto, D.; Jerez, S.; Cejas, J.R.; Martin, M.V.; Acosta, N.G.; Bolaños, A.; Lorenzo, A. Comparative study of lipid and fatty acid composition in different tissues of wild and cultured female broodstock of greater amberjack (Seriola dumerili). Aquaculture 2012, 360-361, 1-9. [CrossRef]

51. Benedito-Palos, L.; Navarro, J.C.; Sitjà-Bobadilla, A.; Bell, G.J.; Kaushik, S.; Pérez-Sánchez, J. High levels of vegetable oils in plant protein-rich diets fed to gilthead sea bream (Sparus aurata L.): Growth performance, muscle fatty acid profiles and histological alterations of target tissues. Br. J. Nutr. 2008, 100, 992-1003. [CrossRef]

52. Piedecausa, M.A.; Mazón, M.J.; García García, B.; Hernández, M.D. Effects of total replacement of fish oil by vegetable oils in the diets of sharpsnout seabream (Diplodus puntazzo). Aquaculture 2007, 263, 211-219. [CrossRef]

53. Richard, N.; Mourente, G.; Kaushik, S.; Corraze, G. Replacement of a large portion of fish oil by vegetable oils does not affect lipogenesis, lipid transport and tissue lipid uptake in European seabass (Dicentrarchus labrax L.). Aquaculture 2006, 261, 1077-1087. [CrossRef]

54. Bouraoui, L.; Sánchez-Gurmaches, J.; Cruz-Garcia, L.; Gutiérrez, J.; Benedito-Palos, L.; Pérez-Sánchez, J.; Navarro, I. Effect of dietary fish meal and fish oil replacement on lipogenic and lipoprotein lipase activities and plasma insulin in gilthead sea bream (Sparus aurata). Aquac. Nutr. 2011, 17, 54-63. [CrossRef]

55. Regost, C.; Arzel, J.; Robin, J.; Rosenlund, G.; Kaushik, S.J. Total replacement of fish oil by soybean or linseed oil with a return to fish oil in turbot (Psetta maxima) 1 . Growth performance, flesh fatty acid profile, and lipid metabolism. Aquaculture 2003, 217, 465-482. [CrossRef]

56. Bell, J.G.; McEvoy, J.; Tocher, D.R.; McGhee, F.; Campbell, P.J.; Sargent, J.R. Replacement of fish oil with rapeseed oil in diets of Atlantic Salmon (Salmo salar) affects tissue lipid compositions and hepatocyte fatty acid metabolism. J. Nutr. 2001, 131, 1535-1543. [CrossRef]

57. Bell, J.G.; Sargent, J.R. Arachidonic acid in aquaculture feeds: Current status and future opportunities. Aquaculture 2003, 218, 491-499. [CrossRef]

58. Torstensen, B.; Frøyland, L.; Lie, Ø. Replacing dietary fish oil with increasing levels of rapeseed oil and olive oil-effects on Atlantic salmon (Salmo salar L.) tissue and lipoprotein lipid composition and lipogenic enzyme activities. Aquac. Nutr. 2004, 10, 175-192. [CrossRef]

59. Saito, H. Lipid characteristics of two subtropical Seriola fishes, Seriola dumerili and Seriola rivoliana, with differences between cultured and wild varieties. Food Chem. 2012, 135, 1718-1729. [CrossRef]

60. Rodríguez-Barreto, D.; Jerez, S.; Cejas, J.R.; Martin, M.V.; Acosta, N.G.; Bolaños, A. Effect of different rearing conditions on body lipid composition of greater amberjack broodstock (Seriola dumerili). Aquac. Res. 2017, 48, 505-520. [CrossRef] 
61. Rodríguez-Barreto, D.; Jerez, S.; Cejas, J.R.; Martin, M.V.; Acosta, N.G.; Bolaños, A.; Lorenzo, A. Ovary and egg fatty acid composition of greater amberjack broodstock (Seriola dumerili) fed different dietary fatty acids profiles. Eur. J. Lipid Sci. Technol. 2014, 116, 584-595. [CrossRef]

62. O'Neill, B.; Le Roux, A.; Hoffman, L.C. Comparative study of the nutritional composition of wild versus farmed yellowtail (Seriola lalandi). Aquaculture 2015, 448, 169-175. [CrossRef]

63. Rombenso, A.N.; Trushenski, J.T.; Drawbridge, M. Saturated lipids are more effective than others in juvenile California yellowtail feeds-Understanding and harnessing LC-PUFA sparing for fish oil replacement. Aquaculture 2018, 493, 192-203. [CrossRef]

64. Seno-O, A.; Takakuwa, F.; Hashiguchi, T.; Morioka, K.; Masumoto, T.; Fukada, H. Replacement of dietary fish oil with olive oil in young yellowtail Seriola quinqueradiata: Effects on growth, muscular fatty acid composition and prevention of dark muscle discoloration during refrigerated storage. Fish. Sci. 2008, 74, 1297-1306. [CrossRef]

65. Fukada, H.; Taniguchi, E.; Morioka, K.; Masumoto, T. Effects of replacing fish oil with canola oil on the growth performance, fatty acid composition and metabolic enzyme activity of juvenile yellowtail Seriola quinqueradiata (Temminck \& Schlegel, 1845). Aquac. Res. 2017, 48, 5928-5939.

66. Bergman, A.M.; Trushenski, J.T.; Drawbridge, M. Replacing fish oil with hydrogenated soybean oils in feeds for yellowtail. N. Am. J. Aquac. 2018, 80, 141-152. [CrossRef]

67. Stuart, K.; Johnson, R.; Armbruster, L.; Drawbridge, M. Arachidonic acid in the diet of captive yellowtail and its effects on egg quality. N. Am. J. Aquac. 2018, 80, 97-106. [CrossRef]

68. Bell, J.G.; McGhee, F.; Campbell, P.J.; Sargent, J.R. Rapeseed oil as an alternative to marine fish oil in diets of post-smolt Atlantic salmon (Salmo salar): Changes in flesh fatty acid composition and effectiveness of subsequent fish oil "wash out". Aquaculture 2003, 218, 515-528. [CrossRef]

69. Stubhaug, I.; Lie, Ø.; Torstensen, B.E. Fatty acid productive value and $\beta$-oxidation capacity in Atlantic salmon (Salmo salar L.) fed on different lipid sources along the whole growth period. Aquac. Nutr. 2007, 13, 145-155. [CrossRef]

70. Ikemoto, A.; Nitta, A.; Furukawa, S.; Ohishi, M.; Nakamura, A.; Fujii, Y.; Okuyama, H. Dietary n-3 fatty acid deficiency decreases nerve growth factor content in rat hippocampus. Neurosci. Lett. 2000, 285, 99-102. [CrossRef]

71. Kitajka, K.; Puskas, L.G.; Zvara, A.; Hackler, L.; Barcelo-Coblijn, G.; Yeo, Y.K.; Farkas, T. The role of n-3 polyunsaturated fatty acids in brain: Modulation of rat brain gene expression by dietary n-3 fatty acids. Proc. Natl. Acad. Sci. USA 2002, 99, 2619-2624. [CrossRef]

72. Kreps, E.M.; Chebotarëva, M.A.; Akulin, V.N. Fatty acid composition of brain and body phospholipids of the anadromous salmon, Oncorhynchus nerka, from fresh-water and marine habitat. Comp. Biochem. Physiol. 1969, 31, 419-430. [CrossRef]

73. Caballero, M.J.; Obach, A.; Rosenlund, G.; Montero, D.; Gisvold, M.; Izquierdo, M.S. Impact of different dietary lipid sources on growth, lipid digestibility, tissue fatty acid composition and histology of rainbow trout, Oncorhynchus mykiss. Aquaculture 2002, 214, 253-271. [CrossRef]

74. Campos, I.; Matos, E.; Maia, M.R.G.; Marques, A.; Valente, L.M.P. Partial and total replacement of fish oil by poultry fat in diets for European seabass (Dicentrarchus labrax) juveniles: Effects on nutrient utilization, growth performance, tissue composition and lipid metabolism. Aquaculture 2019, 502, 107-120. [CrossRef]

75. Pagliarani, A.; Pirini, M.; Trigari, G.; Ventrella, V. Effect of diets containing different oils on brain fatty acid composition in sea bass (Dicentrarchus labrax L.). Comp. Biochem. Physiol. Part B Biochem. 1986, 83, 277-282. [CrossRef]

76. Skalli, A.; Robin, J.H.; Le Bayon, N.; Le Delliou, H.; Person-Le Ruyet, J. Impact of essential fatty acid deficiency and temperature on tissues' fatty acid composition of European sea bass (Dicentrarchus labrax). Aquaculture 2006, 255, 223-232. [CrossRef]

(C) 2020 by the authors. Licensee MDPI, Basel, Switzerland. This article is an open access article distributed under the terms and conditions of the Creative Commons Attribution (CC BY) license (http://creativecommons.org/licenses/by/4.0/). 